\section{El reto educativo de El buen quehacer del médico}

Albert Oriol-Bosch, Arcadi Gual

\section{The educational challenge of The Good Physician housework}

El Consejo General de Colegios Oficiales de Médicos de España (CGCOM) ha hecho público en el mes de marzo de este año 2014 el documento titulado El buen quehacer del médico (accesible en www.fundacioneducaciónmedica.org). Eldocumento fue redactado por un reducido número de expertos que contaron con el apoyo crítico de otros 35 profesionales y de la Fundación Educación Médica (FEM), que dio su apoyo para el desarrollo de la idea, su maduración, redacción y revisión del documento, consenso y adopción final por la profesión médica en el seno del CGCOM. La FEM agradece a esta institución que haya sido el motor imprescindible para llevar a buen puerto esta tarea.

En palabras del Dr. Rodríguez Sendín, presidente de la Organización Médica Colegial, este documento, 'entendido como una pauta de la buena práctica médica, relata la conducta y actitud a seguir por el médico y por tanto debe ser de utilidad no sólo para los profesionales, sino muy directamente para las organizaciones profesionales y para las instituciones responsables de la formación de los médicos'. No es de extrañar pues que la FEM tome este documento, ahora propiedad de la profesión médica, para llevarlo a la comunidad educativa con el fin de que ésta lo incorpore a su propio acervo y le sirva de guía para su buen quehacer educativo. Porque el vigente mandato de Bolonia a orientar el proceso educativo a la consecución de las competencias predefinidas exige los cambios de metodología evaluativa pertinentes y necesarios para conocer el alcance de los logros previstos. Y la medida del nivel competencial alcanzado, es decir, de su aplicación a la práctica profesional, precisa concreciones. El buen quehacer del médico ofrece los marcos conceptuales que se requieren para desarrollar los nuevos procedimientos evaluativos imprescindibles.
In March 2014 the General Council of Official Medical Associations (CGCOM) published a document entitled The Good Physician housework, which can be accessed at www.fundacioneducacionmedica.org. The document was drawn up by a small number of experts with the critical support of another 35 professionals and the Fundación Educación Médica (FEM), which assisted in the development of the idea, its execution, the drafting and revision of the document, and the consensus and eventual adoption by the medical profession within the CGCOM. The FEM is indebted to this institution, which has been the essential driving force allowing this task to be successfully completed.

As stated by Dr Rodríguez Sendin, president of the Spanish General Medical Council, this document, 'understood as a set of guidelines for good medical practice, establishes the behaviour and the attitude a doctor should follow and as such is therefore useful not only to professionals, but also very directly to professional organisations and the institutions responsible for the training of physicians.' It is therefore hardly surprising that the FEM has taken this document, now the property of the medical profession, and handed it over to the educational community to be included within its own pool of resources and to be used to guide its good educational practice. The fact is that the Bologna mandate currently in force, according to which the educational process should be oriented towards achieving the predefined competences, requires significant and necessary changes in the assessment methodology in order to determine the scope of the foreseeable achievements. And there is also a need for greater precision in the measurement of the level of competence reached, that is to say, of its application to professional practice. The Good Physician housework offers the conceptual
Coordinación/Correspondencia: Fundación Educación Médica. Departamento de Ciencias Fisiológicas I. Facultad de Medicina. Universitat de Barcelona. Casanova, 143. E-08036 Barcelona. E-mail: agual@ fundacioneducacionmedica.cat (c) 2014 FEM 
Los ocho ámbitos (profesionalismo, relación médico-paciente, competencia profesional, comunicación y colaboración, relaciones intra e interprofesionales y trabajo en equipo, seguridad y calidad, relación práctica profesional-aprendizaje, y organizaciones sanitarias y sistemas de salud) en que se estructura el documento muestran que la arquitectura actual de los dos primeros ciclos educativos (el grado y la formación especializada) no es en absoluto coincidente.

El análisis que se hace del buen quehacer del médico trata básicamente de elementos operativos que corresponden a lo que en argot educativo se denominan 'competencias transversales'. Desgraciadamente, estas competencias no tienen, hoy por hoy, quien se responsabilice de ellas ni quien las evalúe en nuestras instituciones docentes. Siendo responsabilidad de todos no lo son, en realidad, de nadie. $\mathrm{Al}$ respecto, se ha puesto de manifiesto que cuando aparecen problemas en la práctica clínica, están en juego las competencias genéricas o transversales [1]. De mayor interés resulta el trabajo de Meng [2], que muestra que el éxito en el mercado laboral está más determinado por las competencias genéricas que por las específicas; en consecuencia, es un deber inexcusable potenciar, en los tres periodos de formación de los médicos, el desarrollo y aprendizaje de estas competencias huérfanas: las competencias transversales.

Los ocho ámbitos que desarrolla El buen quehacer del médico no son tan subsidiarios de un proceso educativo formal -con una organización de contenidos, una didáctica específica y una distribución curricular- como del entorno en que el proceso educativo se lleva a cabo. El clima educativo que transpiren las facultades de medicina y el clima de trabajo de las organizaciones asistenciales, hospital o centro de asistencia primaria, son probablemente los mejores recursos disponibles para inculcar -o desarraigar para siempre- las actitudes adecuadas para el buen quehacer del médico. Afortunadamente disponemos de recursos probados para valorar el clima educativo tanto en las facultades [3] como en las instituciones sanitarias [4]. Sin embargo, el clima educativo no es una cuestión que, hoy por hoy, preocupe a los responsables de las respectivas instituciones.

Poner de relieve que el proceso educativo debe conducir a la obtención de un producto capaz de actuar de acuerdo a lo prescrito en El buen quehacer del médico ayudará a que los responsables institucionales se interesen por el clima educativo y de trabajo en sus organizaciones y facilitará que las decisiones de estos responsables conduzcan al lo- frameworks required to implement the new essential evaluative procedures.

The document is structured in eight domains (professionalism, physician-patient relationship, professional competence, communication and collaboration, intra- and inter-personal relationships and teamwork, safety and quality, professional practicelearning relationship, and healthcare organisations and health systems), which show that the current architecture of the first two educational cycles (bachelor's degree and specialised training) does not match this at all.

The analysis of good practice for doctors basically deals with operational elements that correspond to what are known in educational jargon as 'cross-curricular competences.' Unfortunately, today, nobody takes responsibility for these competences or evaluates them in our teaching institutions. Since they are everyone's responsibility, in actual fact, nobody feels responsible for them. In this regard, it has been shown that when problems arise in clinical practice, what are at stake are generic or cross-curricular competences [1]. More interesting still is the work by Meng [2], who points out that success on the labour market is determined more by generic competences than by specific ones. As a result we have an unquestionable duty to improve, within the three periods of doctors' training, the development and learning of these 'disowned, that is to say, cross-curricular competences.

The eight domains developed in The Good Physician housework are not as amenable to a formal educational process (with formally organised contents, a specific teaching method and a curricular distribution) as they are to the setting in which the educational process is carried out. The educational climate within the faculties of medicine and the work climate in healthcare organisations, hospitals or primary care centres are probably the best resources available for instilling -or eradicating once and for all-attitudes that are appropriate to doctors' good practice. Fortunately, there are tried and tested resources for evaluating the educational climate both in faculties [3] and in healthcare institutions [4]. Yet, the educational climate is not an issue that, today, concerns those in charge of the respective institutions.

Highlighting the fact that the educational process must lead to the attainment of a product that is capable of acting in agreement with what is set out in The Good Physician housework will help those responsible for the institutions to take an interest in the educational and work climate in their organisations, while also helping to ensure that the decisions they make will be conducive to achieving the desired 
gro de los objetivos deseados. Conocer la situación real del clima institucional y los progresos en sus respectivas instituciones es, como se ha señalado, posible mediante instrumentos tan disponibles y validados como ignorados hasta el momento actual.

El reto que este documento plantea a las instituciones educativas es la necesidad de abandonar la confortable territorialidad de la propia materia o especialidad para asumir conjuntamente los retos que afectan al ámbito común donde es imprescindible corresponsabilizarse con todos los demás. aims. Knowing the real situation of the institutional climate and the progress made in their respective institutions can be accomplished, as has been pointed out above, through the use of instruments that to date have been just as neglected as they are as available and valid.

This document calls for educational institutions to abandon the comfort zone of their own subject or specialty to take on joint challenges that affect the common domain where it becomes essential to share responsibility with all the others.

Bibliografía / References

1. Van der Vleuten CP, Schuwirth LW, Scheele F, Driessen EW, Hodges B. The assessment of professional competence: building blocks for theory development. Best Pract Res Clin Obstet Gynaecol 2010; 24: 703-19.

2. Meng C. Discipline-specific or academic?; acquisition, role and value of higher education competencies. ROA Dissertation Series no. 8. Maastricht: Research Centre for Education and the Labour Market; 2006.

3. Genn JM. Curriculum, environment, climate, quality and change in medical education -a unifying perspective. AMEE Medical Education Guide no. 23. Med Teach 2001; 23: 445-54.

4. Roff S, McAleer S, Skinner A. Development and validation of an instrument to measure the postgraduate clinical learning and teaching educational environment for hospital-based junior doctors in the UK. Med Teach 2005; 27: 326-31. 


\section{Revisores de la revista FEM 2013}

El Comité Editorial agradece la tarea llevada a cabo por los revisores de la revista durante el año 2013:

Altisent Trota, Rogelio

Aracil Marco, Adolfo

Arráez Aybar, Luis Alfonso

Baños Díez, Josep Eladi

Bosco López, José Juan

Brailovsky, Alberto Carlos

Branda Riesco, Luis Alberto

Camps, Remei

Centeno, Ángel

Clèries Costa, F. Xavier

Costa, Manuel João

Escanero Marcén, Jesús Fernando

Fornells Vallés, Josep M.

Gomar Sancho, Carmen

Gual Sala, Arcadi

Icart Isern, M. Teresa
Lafuente, Amalia

Lahera, Vicente

Macarulla Sanz, Enric

Millán Núñez-Cortés, Jesús

Molinuevo Alonso, Beatriz

Monzó Planella, Mariano

Nolla Domenjó, Maria

Palés Argullós, Jordi

Pastor, Xavier

Pérez de Galli, Amanda Elisa

Pérez Sánchez, Jordi

Prat, Joan

Sanz Álvarez, Emilio

Segura Benedicto, Andreu

Vendrell Gómez, Pere

Villanueva, José Luis 